\title{
The importance of the pedagogical political project for school management
}

\author{
Maria José De Lima Silva Andrade; Teresa Amelia Barros de Souza²; Emanuella Barros de Souza \\ Oliveira Álvares*3
}

1. Specialist in Educational Management.

2. Professor of the Academic Center of Vitória de Santo Antão - UNIVISA

3. Professor at the Academic Center of Vitória de Santo Antão - UNIVISA

E-mail adresses: mlimaandrade2011@bol.com.br (Maria José de Lima Silva Andrade), teresa.amelia@hotmail.com (Teresa Amelia Barros de Souza), emanuelabarros@univisa.edu.br (Emanuella Barros de Souza Oliveira Álvares).

${ }^{*}$ Corresponding author

\section{To cite this article:}

Andrade, M.J.L.S.; Souza, T.A.B.; Álvares, E.B.S.O. The importance of the pedagogical political project for school management. International Journal of Sciences. Vol. 2, No. 2, 2021, pp. 13-17. ISSN 2763-5392.

Received: 08 10, 2021; Accepted: 08 11, 2021; Published: 09 06, 2021

\begin{abstract}
This academic research work has as its theme the importance of the Pedagogical Political Project (PPP) for Management and has as its general objective to recognize its relevance to school management. In the course of the text, it is perceived that the PPP functions as a fundamental working instrument for a management that is concerned with organizing the pedagogical activities and active management of the institution seeking to promote quality teaching. Based on a bibliographical research, the article is composed of topics relevant to the theme explaining the concept, principals and the contributions of the PPP to a school management. The main theoretical reference was the texts of the author Lima Passos Veiga, by the author José Libêneo and Celso Vasconcelos, which demonstrate that the school organization is complex and must be thought and intentional in such a way that a management that values dialogue and the exchange of ideas makes all the difference in the school's results.
\end{abstract}

Keywords: Pedagogical Political Project; School Management; Decentralization; Autonomy.

\section{Introduction}

This article addresses the importance of the Pedagogical Political Project (PPP) for School Management, emphasizing it as a fundamental element for the execution of administrative and pedagogical tasks in order to obtain a quality education. The theme addressed is justified by its pertinence because it is understood that the Political Pedagogical Project functions as an ally for school management that cares about the good performance of its team, aiming to meet the needs of its student.

In addition to understanding that every school has its own identity, a different reality, distinct needs and diverse challenges, the political pedagogical project can be a work instruction in which the manager with the school community come to guide all the activities of the school serving as an aid to overcome the challenges through the proposals presented in the preparation of this document.

The general objective of this article is to recognize the importance of the Pedagogic Political Project for school management. And the specific objectives are discriminated in identifying the function, principles and structure of the PPP, understanding the basic aspects that should contain a pedagogical political project and analyzing the performance of the manager in the preparation of this document.

The reflections presented in this article are based on a bibliographic survey, being the LDB of 1996, the Constitution of 1988, and Lima Passos Veiga (2002), some of the theories that served as a basis for the construction of this text. According to what has already been published, the elaboration of the Political Pedagogical Project is a legal requirement that needs to be transform ed into reality by all institutions of the country, but it is important to emphasize that itis not only a question of complying with the law, but of providing a moment of construction, organization and autonomy of the school, ensuring a democratic management where all school members participate and share decisions in order to solve the problems existing in the institution, in addition to establishing objectives and goals that will guide all future activities. 


\section{Pedagogical political project - concept}

In the etymological sense, the term project comes from the Latin project, past participle of the verb projicere, which means to cast forward. Plan, intent, design. Company, enterprise. Provisional drafting of law. General building plan (Ferreira, 1975, p.1.144 apud Veiga 2002).

The LDB (Law of Guidelines and Bases of Education 9394/96) emphasizes the importance of this document in order to give autonomy to schools in the elaboration of their own identity, through the construction of differentiated projects according to the needs of each institution.

In Article 12, item I, which has been called the "school article" the Law gives educational establishments the task of elaborating and executing their pedagogical proposal.

This document details objectives, guidelines and actions of the educational process to be developed in the school, expressing the legal requirements of the educational system, as well as the purposes and expectations of the school community, expresses the culture of the school and aims to contribute to transform it. Libâneo $(2004$, p.52) states that:

The pedagogical political project can be compared, analogously, to a tree. That is, we plant a seed that sprouts, creates and strengthens its roots, produces shade, flowers and fruits that give rise to other trees, fruits..., but to keep it alive, it is not enough to water it, fertilize it and prune it only once.

In this perspective, the pedagogical political project is not something that should be constructed and soon after it is filed, it is not only a bureaucratic instrument, but an institutional mechanism of autonomy and emancipation that must be experienced at all times by all involved with the educational process.

The project is an intentional action, seeks a direction, a direction, with a collectively defined commitment, so every pedagogical project of the school, is also a political project because it considers the school as a space for the formation of conscious and critical citizens who will act individually and collectively in society, modifying the directions it will follow. And it is pedagogical because it defines and organizes the educational activities and projects necessary for the teaching and learning process.

It is up to the school to define what type of citizen wants to train, according to its vision of society, assuming the responsibility of acting in the transformation and pursuit of social development, so that its agents are committed to the elaboration of a proposal to achieve this goal.

\section{1 principles}

The main principles that guide the pedagogical political project are: participation, democratic management, autonomy and collective work.

\section{Participation}

In Article 14 of the Law of Guidelines and Bases of Education/1996 in which the principles of democratic management are defined, the first is the participation of education professionals in the elaboration of the pedagogical project of the school. Article 12, item VII defines the school's task of informing parents and guardians about the frequency and performance of students, as well as on the execution of their pedagogical proposal.

In Article 13 of the LDB, called the "teachers' article", the tasks of this segment appear, among others, to participate in the elaboration of the pedagogical proposal of the educational establishment, to elaborate and comply with a work plan, according to the pedagogical proposal of the educational establishment.

It is extremely important to the participation of all who make the school community in the elaboration of the political pedagogical project, is a moment of reflection where each one must express his opinions with regard to the difficulties and needs of the school in its entirety. Vasconcelos (2004, p.25) the firm that:

By participation, the individual can assume the condition of subject and not object. In this sense, it is relevant that there is an active participation in order to achieve achievements such as the elaboration of the pedagogical political project itself and the ideas foreseen by it.

It is perceived how much many schools leave to be desired in their meetings of parents and teachers who are limited to long and informative meetings, where parents enter and leave and contribute little to school and so little to school with them. The school needs to listen to what the fathers, mothers and guardians want, give value to their ideas, desires and contextualize them to the life of the school, but they must also listen, participate in what the school intends to accomplish, and together build a participatory school space.

\section{Democratic management}

Democratic Management is a principle enshrined by the current Constitution and covers the pedagogical, administrative and financial dimensions. This principle aims to promote decentralization, in which administration, decisions, actions must be elaborated and implemented in a non-hierarchical manner.

Participation is another principle in which all those involved in school daily life must participate in management: teachers, students, employees, parents or guardians, and the whole community around the school. And transparency so that any decision and action taken or implemented in the school has to be known to all. According to Marques (1990, p.21):

Broad participation ensures the transparency of decisions, strengthens the pressures for them to be legitimate, ensures control over the agreements established and, above 
all, contributes to the contemplated issues that would not otherwise come into account. It is understood that democratic management within the school is not a simple and easy to implement, it is a critical participation with regard to the construction of the PPP and its management.

\section{Autonomy}

Being also a guiding principle of the Political Pedagogical Project, autonomy is an element of paramount importance in the construction of it, because it characterizes the moral and intellectual freedom of the school, as well as its administrative independence, going beyond the filling of forms just to comply with protocols.

For Libâneo (2001, p. 115) autonomy is "the reason for being the pedagogical project", thus referring us to the indispensable function of autonomy for the construction and execution of the PPP. The autonomy of the school must prevail in all its aspects, physical, administrative and over all pedagogical, since each school is unique, and has a very specific reality, which makes it necessary to develop strategies that meet the peculiarities of this space.

Neves (2002, p.99) recalls that "(...) autonomy places in the school the responsibility to account for what it does or does, without passing on this task to another sector (...). Therefore, it is worth noting that the school cannot demand this function from any other body of the Educational System, because its practice is non-transferable. Its action, its articulation and its understanding of the public it serves, are essential for the realization of a collective work in partnership with students, parents, teachers and managers.

\section{Collective work}

This collective work is part of the guiding principles of the PPP, because the school is a collective space, it needs the work to be carried out in a decentralized way where everyone who is part of the school community has the right and duty to decide, plan and execute the actions.

The participation according to Libâneo (2001, p. 79):

It provides a better knowledge of the objectives and goals, the organizational structure and its dynamics, the school's relations with the community, and favors a greater approximation between teachers, students and parents.

The management team needs to think about how to manage in a way that ensures the participation of all of the group, creating opportunities for involvement and development since "teamwork is an inexhaustible source of overcoming and valuing the professional" (Nogueira 2008, p.01).

Collective work will only bring benefits, because working together for the same goal, which certifies the quality of teaching and learning, professionals and other members of the school community will feel encouraged to overcome any obstacles. And so, the relationship between the team will be enriched.

When decisions are made as a team, the doors of resistance are closed and everyone collaborates as they were also part of the choice. Therefore "dialogue must be frank, even discussing openly", as Vasconcellos (2006, p.100) says. If there is dialogue, there will also be the collective of the group in the realization and realization of the actions. Since everyone has a voice and once in the preparation of the PPP, they will have greater commitment to the execution of the same in the daily life of the school.

\section{2 structure}

Knowing that the PPP is a document of the school that also meets an obligation before the Law governing education in the country (LDB 9.394/96), it is essential to deal here about its structure. Because even though the educational institution is authentic and peculiar, the project needs to meet some criteria in order to have its effectiveness recognized and valid.

It is worth noting that there is no ready, predetermined model for the construction of the same "(...) the important thing is to say clearly what the school will actually do, based on its conditions (...)" (PADILHA, p. 90).

As it is the product of a collective work resulting from the involvement of the various members of the school community, to plan and organize the pedagogical and administrative development of the school, in order to improve the work developed and seek solutions to the conflicts encountered, it needs to reveal its mission, its vision and its values, as well as the goals it wants to achieve and how it will carry out the actions to achieve its objectives. In this construction everyone is willing to achieve the same goal, so they need to have the same purpose that is "the commitment of all students who need to learn" (Furlanetto, 2007). The focus of the educational process will always be the student, he is the reason for the existence of the school.

Although there is no predetermined model for the construction of the Political Pedagogical Project, it is important to highlight at least seven basic elements that should be considered: the purposes of the school, the organizational structure, the curriculum, school time, the Deci process, the work relations and the evaluation.

\section{Purposes}

It is extremely important that educators have clarity of the purposes of their school and decide together where they want to arrive, what needs to be improved, so that they can be reached and the goals, which must be the same for the whole team.

The following questions should be raised and reflected, generating answers and solutions to the success of the school.

- What kind of society do we want to build?

- What purpose do we want for school?

- What role do we want for the school in our reality?

This work of reflection on its educational purpose 
should be the primary task of the school. Within the perspective, the school seeks to base the concept of autonomy, emphasizing the responsibility of all. Nóvoa tells us that autonomy is important for: "the creation of a school identity, a scientific and differentiating ethos, which facilitates the support of the various actors and the elaboration of its own project"(Nóvoa, 1992, p. 26 apud Veiga 2002). Autonomy refers to the emancipation of education, an autonomous school creates and executes its Political Pedagogical Project, assuming a leadership attitude in which the political, social and cultural ideas of the school are defined.

\section{Organizational structure}

The school generally has two basic types of structures: administrative and pedagogical. Administrative structures refer to human, physical and financial resources. All the elements that have a material form such as: the architecture of the school building and the way in which it is presented from the point of view of its image are still part of the administrative structures: equipment and teaching materials, furniture, distribution of dependencies and free spaces, colors, cleaning and basic sanitation (Veiga 2002).

With regard to pedagogical structures, these determine the actions of the administrative, are related to political interactions, teaching and learning issues and curriculum issues. In the pedagogical structures are included all the sectors necessary for the development of pedagogical work

\section{Curriculum}

The school curriculum is very important because it is an instrument that guides the three-year-old involved in the school and expresses the social and cultural context through the transmission of school knowledge, that is, through the contents that must be related to the day-to-day life of the students so that the learning is meaningful.

In the curricular organization it is necessary to consider that the curriculum is not a neutral instrument, pois the curriculum passes ideology, expresses a culture, it cannot be separated from the social context because it is historically situated and culturally determined.

\section{School time}

The school calendar is an indispensable element of the organization of the school curriculum, because it shows the number of hours that teachers of each subject will have to use in the classroom, evaluations, courses, periods in which the year is divided, holidays, holidays, school days, extracurricular activities (such as interclass championships, June party, among others) and pedagogical activities (such as collective work in school, class council and etc.)

The school should reformulate its time so that students have time to organize and create their space beyond the classroom. Teachers also need time to get to know their students better and to participate in continuing education courses and lectures, prepare classes, didactic activities, evaluations, and follow the Pedagogical Political Program in action.

\section{Decision-making process}

In the formal organization of a school, the flow of tasks, actions and decisions are guided by formalized procedures, prevailing hierarchy and centralizing power (Veiga 2002). However, it is important that the school review this concept and promote mechanisms that stimulate the participation of all in the decision-making process.

\section{Working relationships}

The working relationships that take place within the school must be based on dialogue, solidarity, reciprocity and collective participation. Only from this perspective can power decentralization occur. According to Machado, the process of struggle is a way of being against domination, and may contribute to the articulation of emancipatory practices" (Machado 1989, p. 30 apud Veiga 2002). From this perspective new information of power can be built from within the classroom and the school.

\section{Evaluation}

The evaluation process leads the school to reflect based on concrete data on how the school is putting into action the Political Pedagogical Project. From the evaluation, the actions of educators and students are directed.

Evaluation cannot be an instrument of exclusion, but of collective growth through reflection on the identification of problems and alternative actions.

\section{The contributions of a pedagogical political project for school management}

The Political Pedagogical Project has been the subject of studies since the nineties and appeaser to be a welldiscussed topic, its construction and implementation is still a challenge for many schools.

The PPP represents the school, since it comes to show its organization, its practice pedagogic and administrative, through continuous process that involves several education professionals and its relationship with the community.

It is perceived, therefore, that a Pedagogical Political Project when elaborated constructively and emancipatory is a collaborative element for school management facilitating the execution of daily activities.

Historically, the administration of education in Brazil has been moved between bureaucratization, school structure and the management of funds. This totally technical model no longer corresponds to the needs of a school administration, so that today, school management needs to be able to present globalized and interdisciplinary solutions to problems. 
Today more than ever improvements are also charged in the quality of educational services in general, taking into account the capacity of each person to build knowledge, as a subject who thinks, acts, does, reflects... (Veiga 2006)

In view of this, it is essential that school management take on a new management profile, so that it will promote decentralization in the internal environment of the school, as well as the decentralization of the educational system.

The Politic Pedagogic project is a democratic instrument that contributes to this decentralization, since the preparation of this document opportunities dialogue and the exchange of ideas among the agents who form a school, in addition to promoting the autonomy of the school, due to the uniqueness of each PPP, which needs to be in accordance with the needs and difficulties of each institution.

Democratic practice means that decisions are preceded by discussions. The decisions are made based on what is best for all's, privileging the interests of the collective, overcoming individualism.

The great deafen of organizations is change. Environmental transformations require intense and permanent decision-making activity, but it is necessary to take into account that every decision needs to be monitored, so that if there are needs for adjustments, these are made, and the decision itself can be reformulated, because it is not final.

However, it is noted that articulating, elaborating and building a Political Pedagogical Project, own and constantly improving is a great challenge, but it is not impossible, as long as school management seeks to improve the quality of its educational services and the results of these services. Services that generate technical training, intellectual production and autonomous individuals. The implementation of the PPP is indispensable for the construction of the school's identity, as a necessary pedagogical space for the building of knowledge and citizenship.

Taking into account everything that has already been addressed it is clear that the reason for the existence ofthe school is not to be administered the supervised $u$, but it is to be a space in which children, young people, parents, teachers and managers, relate to each other, creating opportunities for everyone to develop, build and rebuild knowledge.

\section{Conclusion}

The Pedagogical Political Project being a guide tool of the pedagogical activities of the school show the whole organization, goals and institutional objectives. The PPP is also seen as the identity of the institution and must be in agreement with the local reality of the school and the students.

It is extremely important that in the construction of the PPP the whole schoolcommunity participates, because it must be prioritizedthe interests aimed atimproving education and for this it is necessary that they are inthesame purpose; managers, teachers, alumni's and parents of students, where dialogue and the exchange of ideas serve as the basis for the elaboration of the PPP. It is also important to emphasize that the Politico Pedagogical Project isnot only a document that the management of escola keeps stored in thedrawer, but on the contrary is a document that should always be under construction, with regard to the expectations of the school through a process that involves actions and evaluation of the results of these actions.

For the school to truly achieve its goal of forming critical and autonomous citizens, it is essential that school management value the collective so that decisions are democratic and that the process of evaluation and review is a constantpractice, providing opportunities for reflection for changes in paths and direction.

In the school we live in today, it is not possible to be directed from the top down, the fight of the school is fordecentralization in search of its autonomy and quality. The autonomy that one wishes to achieve is that the school can choose its course, its path, and make its own future, its own history, of its culture and reality, which is different for each school.

It is concluded that collective work, the commitment of education professionals, the valorization of the reality in which the school is inserted and political intentionality are extremely necessary ingredients for the construction and execution of the Political Pedagogical Project.

\section{References}

[1] BRASIL. Constituição da República Federativa do Brasil. Brasília, DF: Senado, 1988.

[2] BRASIL - Lei de Diretrizes e Base da Educação Nacional LDBEN 9.394/96

[3] FURLANETTO, Ecleide Cunico. Como Nasce um Professor.4 Ed São Paulo: Paulos, 2007

[4] LIBÂNEO, José Carlos. Organização e gestão da escola: teoria e prática. Goiânia: Alternativa, 2001. Educação escolar, políticas, estruturas e organização. 2 ed. SP: Cortez, 2005.

[6] MARQUES, Mário Osório (1990). Projeto Pedagógico: A marca da escola". Revista Educação e Contexto. Projeto pedagógico e identidade da escola, $\mathrm{n}^{\circ}$ 18. Ijuí: Unijuí, abr.jun

[7] NEVES, Carmem Moreira de C. Autonomia da escola pública: um enfoque operacional. In VEIGA, Ilma Passos A. (Org) Projeto Político Pedagógico da Escola: uma construção possível. Campinas, SP; Papirus, $15^{\mathrm{a}}$ Edição, 2002.

[8] NOGUEIRA, Vanessa dos Santos. O papel do coordenador pedagógico. Colunista Brasil Escola. Disponível em $<$ http://pedagogia.brasilscola.com/trabalhodocente/o-papelcoordenador-pedagogico.htm $>$. Acessado em: 01de janeiro de 2015.

[9] PADILHA, Paulo Roberto. Planejamento dialógico: como construir o projeto político pedagógico da escola. São Paulo; Cortez, 2001.

[10] VASCONCELlOS, Celso dos Santos. Projeto PolíticoPedagógico: Educação Superior. Campinas, SP; Papirus, 2004. Coordenação do trabalho pedagógico:

do projeto político ao cotidiano da sala de aula. São Paulo: Libertad, 2006.

[12] VEIGA. Ilma. Passos (Org.) Projeto Político - Pedagógico da 
escola: Uma construção possível. $14^{\circ}$ Edição. São Paulo.

Papirus. 2002. 